\title{
THE CREATIVE PROCESS IN SANDBURG'S "PRAYERS OF STEEL"
}

\author{
Sigrid Renaux \\ Universidade Federal do Paraná
}

\section{SUMMARY}

The aim of this analysis is to show how Carl Sandburg, one of the pioneers of "The Little Renaissance" in American poetry, was able to project, through his poem "Prayers of Steel", not only many characteristics of the new poetry but he succeeded in making the poem become iconic of the creative process the artist is passing through, while working on his work of art.

"The Little Renaissance" in American poetry, which took place in the decade before the First World War, and which represents one of the fundamental shifts in the history of art, has as one of its exponents the figure of Carl Sandburg (1878-1967). By breaking with traditional poetic forms and by widening the range of experience presented in the subject matter of poetry, by adopting new poetic modes and methods, such as formal experimentation, concreteness, the use of the contemporary American scene, the spoken American language, free verse and even discontinuous composition, Sandburg and many other pioneer poets - such as Robert Frost, W.C.Williams, Amy Lowell, Ezra Pound, E.A.Robinson, Vachel Lindsay, Edgar L. Masters - succeeded in bringing American poetry into a new flowering, after such a long period of relative barrenness of the Genteel Tradition following the death of the great Romantic poets and nove-ists.

It is exactly to present Sandburg's modernity that we would like to analyse one of his poems, "Prayers of Steel", 
for in this poem, as in many others, Sandburg has contributed not only to the development of modern poetry but has also made "Prayers of Steel" become iconic of the creative process the poet or artist is passing through. As Leech and Short comment,

a code is iconic to the extent that it imitates, in its signals or textual forms, the meanings that they represent. (...) language, for all its arbitrariness, is in various ways an iconic mirror of reality. It is in the nature of literature to exploit these iconic possibilities; to bring out associations between form and meaning which are ordinarily dormant. (...) It [iconicity] embraces not only onomatopoeia and sound symbolism, but the miming or enactment of meaning through patterns of rhythm and syntax. ${ }^{1}$

And "Prayers of Steel", although generally classified among Sandburg's famous big city poems - as Sandburg established himself as the great voice of the Middle West of the U.S.A. - is actually not only that, but also a lyric and philosophical poem, thus showing once more how classifications in relation to subject matter fall short of the true range and meaning of a poem.

\section{Prayers of Steel}

Lay me on an anvil, O God.

Beat me and hammer me into a crowbar.

Let me pry loose old walls.

Let me lift and loosen old foundations.

Lay me on an anvil, O God.

Beat me and hammer me into a steel spike.

Drive me into the girders that hold a skyscraper together. Take red-hot rivets and fasten me into the central girders. Le me be the great nail holding a skyscraper through blue [nights into white stars."

1 LEECH. O.N. D SHORT, M. Style in fiet:on. LOndon. LOnEmsn. 1981, p. 233.5.

2 GANDBURO. a. Prajers of steel. In: FURLER, E. \& KINNICK, B.J. Adventures in American titerature. Nex York. Harcourt. Brace \& World. 1963. v. 2. p. 199. 
The title of the poem already suggests a paradox, apparent not only in the figure of speech - personification - for steel is given the human power to speak and utter prayers, but also in the contrasts that arise from the two nouns "prayers" and "steel": both contain the opposition human/ non-human, as also the oppositions soft/hard, immaterial/ concrete, singular/plural, formal/formless. The addresser steel - is also immediately apparent in the title, with the further connotation that whatever steel wishes to have accomplished in "his" prayers, will demand strength and hard work.

As can be seen from the visual patterning, the poem is composed in the form of two prayers, of irregular line lengths, which develop from short $(7,8,6,7$ words in the four lines of the first prayer) to long $(7,9,10,11,15$ words in the five lines of the second prayer). Thus the second prayer has not only one line more than the first one, but the last line of the poem has actually the double number of words than the first line. In this way, the lineation of the poem already presents a break with traditional patterns, besides suggesting that the prayers of steel become gradually longer and bolder, which will be later confirmed in the other aspects of the poem.

The sound scheme also presents some striking charac. teristics, considering what had been done during the preceding period of poetry. End rhyme is ignored, as well as the number of syllables and accents in determining the pattern of the poem, and a complex system of sound parallelism takes their place, in this. way binding the words much more together, in sound and meaning, than perhaps a traditional rhyme scheme would have done. We just have to follow the poem line by line in relation to sound effects, to become aware how sound enacts meaning, how even sounds have an iconic potentiality to bring out associations between form and meaning, as Leech and Short comment above.

"Lay me on an anvil, O God": all the consonants of the tirst part of the line are liquids and nasals $(/ 1 /, / \mathrm{m} /, / \mathrm{n} /)$ and fricatives $(/ \mathrm{v} /)$, suggesting softness, which is reinforced by the fact that the two consonants of the second part of 
the line, $/ \mathrm{g} /$ and $/ \mathrm{d} /$, are members of the voiced category and this also suggests softness. The interlacing of phonological repetition in $/ 1 /$ and $/ \mathrm{n} /$ and of the rowel sounds $/ a e$, and $/ 0$ creates in suci a short line a sonority which will be further developed in the following lines, thus helping to hold the lines of the poem very tightly together in relation to the sound scheme. Besides, the very absence of harsh sounds in this first line suggests a state of expectancy in these prayers uttered in \& subdued voice, and, by association, it also suggests or marks the beginning of the creative process.

This softness is then shattered in the next line - "Beat me and hammer me into a crowbar" - for the monossylabic words of line 2 no longer have the liquid characteristics of the first line. The plosives $/ \mathrm{b}, \mathrm{t}$ ' and $/ \mathrm{k}$ ' of "beat", "into" and "crowbar", plus the openness of the ae vowel in "hamner" (reechoing the openess of "anvil") confirm the increasing hardness of this line, in comparison with the line before. The acts of hammering and beating steel on an anvil by a steelworker seem in this way to be projected, and reenacted, in the phonological scheme of this line, and steadily increased by the trochaic beginning of every line in the poem. The simost complete predominance of monossyllabic words (62) over dissyllabic (17) and trissyllabic (4), also confirms the strong simplicity of the poem, giving to it a memorable rinythm and force, and corroborating, from beginning to end, the suggestion of steel being beaten "into" sometning, suggesting again in this way the creative process in progress.

The next two lines emphasize even more the repetitive pattern that is gradually being established:

"Let me pry loose old walls.

Let me lift and looser old foundations".

We have not only many instances of alliteration in these two lines (which starts with "lay" in line 1 and continues with "let", "lift", "loose", "loosen") but also of variations of assonance ("an", "anvil", "and", "hammer"; "O", "crowbar", "old"; "God", "wall", "on"). This repetitive pattern is even more foregrounded when we become aware of the repetition of the pronoun "me" in subordinate position to the verbs 
"lay", "hammer", "beat", "let", which, as already mentioned, carry the stress by their position at the beginning of each line or idea, and also by the fact that they are in the imperative mood.

The same phonological effects take place in relation to the second stanza of the poem. Line 5, "Lay me on an anvil, O God", is a repetition of line 1 ; and line 6 "Beat me and hammer me into a steel spike" is a partial repetition of line 2 , for "crowbar" is substituted by "steel spike". The alliterative effects of /st' and /sp/ plus the hardness of the plosives $/ t$ and $p$ / remind us again of the hardness of metal, in the same way that the short monossylables suggest the incisiveness of a steel spike. Besides, the parallelism in sound established between lines 2 and 6 will later be confirmed on the level of grammar and lexicon.

Lines 7 and 8 ,

"Drive me into the girders that hold a skyscraper [together.

Take red-hot rivets and fasten me into the central

[girders".

present other phonological similarities, such as the repetition of the consonant cluster / $\mathrm{dr}$ / of "drive" in inverted position in "girder", the repetition of the diphthong /ai/ in "drive" and "sky", the rhyming effect of "girders", "skyscraper" and "together", plus many instances of alliteration: "red" and "rivets", "hot" and "hold" reechoing the alliteration with "hammer" of lines 2 and 6 and even the alliteration of "steel spike" in line 6 is repeated and amplified in the world "skyscraper". Other minor sound effects would be the repetition of the /s/ sound in initial, medial and final position in "central", "fasten" and "rivets".

But it is in the last line of the poem,

"Let me be the great nail holding a skyscraper through [blue nights into white stars".

that the phonological schemes are enhanced even more, with the retalking of all these sound patterns in what is also the 
longest line of the poem: "let", as in the first stanza, alliterates with "lay"; "night" with "nail"; the back vowel / i/ of "me" is repeated in "be"; the assonantal effect of "great", "nail" and "skyscraper" reecho "lay", plus the rhyming effect of "through/blue" and "nights/white, all of them again helping to establish a close relationship between all the words in relation to sound.

Thus, by a series of phonological effects, be it repetition, parallelism, alliteration, assonance and the reachoing of certain consonants and vowels in different lines and positions, the poem creates an analogical structure with the very creative process: by enacting the sounds of a steelworker hammering on the anvil through the moving from soft sounds in line 1 and 5 - the beginning of the prayers and of the process - to the presence of lines of increasing hardness marking the beginning of the transformational process lines $2,3,4,6,7,8$ - all of them slibordinate to the beating rhythm introduced by the stressed monosyllables which govern each line. Besides, as mentioned, this creative process is reinforced by the visual patterning of the lines from short to long, this asymmetry corroborating the ever bolder wishes that steel utters, up to the point in which steel wishes to be "the great nail holding a skyscraper together through blue nights into white starts".

We cannot forget, however, that steel, or "me" - as it is referred to in the poem - is in subordinate position to the imperatives "lay", "beat", "hammer", "let", "drive" and "fasten", thus connoting complete passivity in relation to the action of the verbs. This again suggests a paradox, for steel, aithough the addresser, is asking to be transformed into something else, and thus is the receiver of the action of the verbs as also in relation to the creator, or giver, God, to whom the prayers are addressed. The fact that all the lines are end-stopped also confirms the series of complete wishes expressed in each line. In this way, the beating effect in the poem does not depend exclusively on sound, but also on the stacatto brought forth by the end-stopped lines, which help to convey the impression of an accomplished wish a: action at the end of each line. 
Leaving the level of Realization - phonology and graphology - let us now discuss the level of Form - grammar and lexicon - to become aware of even more striking aspects in the poem.

In relation to articles, we move from indeterminacy to determinacy, for "prayers" and "steel" have no article, while "anvil", "crowbar" are preceded by the indefinite article, and "walls" and "foundations" are again indeterminate. This could suggest, in relation to the first prayer, the formless state of steel at the beginning of the poem, to a formal state in "crowbar", but still indeterminate enough to be simply " $a$ " crowbar, any crowbar used as a tool in demolishing old walls and foundations, which are again without identification, for they are going to be removed and have lost their specificity.

In the second prayer, this move from indeterminacy to determinacy becomes more intense, for steel becomes " $a$ " steel spike - as it had become "a crowbar" - to then become, in the last line of the poem, "the" great nail holding a skyscrapper through blue nights into white stars, the lack of articles in "blue nights" and "white stars" emphasizing the uniqueness of this great nail, in relation to " $a$ " skycraper and to the plurality and indeterminacy of "blue nights" and "white stars".

There is also a great ascendancy of verbs over nouns (16 imperatives plus one verb in the past participle and one in gerund form) projecting the continual activity carried out in the poem, while the only "static" verb, "be", in the last iine, asserts again the end of this activity or of this creative process, steel having reached a state of unchangeability and form - the boldest wish expressed in the poem. The great movement given to the lines through these verbs corroborates, on the level of Form, the beating rhythm and movement discussed in relation to sounds and stressed monosyllables.

The extensive use made of the preposition "into" -5 times - with its two meanings, either indicating transformation and change of condition, as in "into a crowbar" and "into a steel spike", or expressing motion or direction to the inside as in "into the girders", "into the central girders" and 
"into white stars", demonstrates how Sandburg actually manages to bring these two different ideas together, of transformation and motion, through grammatical parallelism. In this way, the foregrounding of the preposition "into" in reiation to "on" and "through" confirms its relevance concerning the creative process, for "into" becomes not only responsible for the t:ansformation but also for the motion in space that steel undergoes.

Looking at the color adjectives "red-hot rivets" and "blue nights" and "white stars", we observe again how they confirm this movement from kinesis to stasis already commented on, for red-hot suggests a burning state while blue and white suggest, besides distance, also coldness and stasis, if compared to the nearness and immediacy of the "red-hot rivets".

$\mathrm{Bui}$ it is the examination of the concrete nouns that brings out once more some striking aspects if we group these nouns according to certain common semantic fields or paradigms:

1. nouns related to the construction or tearing down of builaiings: steel, anvil, crowbar, valls, foundations, steel spike, girders, nail, skyscraper;

2. nouns related to nature and the infinite: nights, stars.

Applying this same paradigmatic model to the verbs already mentioned, we vould have a tripartite division which confirms again the movement from a pre-formal state (lay, beat, hammer) to destruction (pry, lift, loosen) to construction (drive, take, fasten). The paradoxical nature of the creative process thus becomes apparent again, for in order to build, one has to tear down the old "foundations" first in order to place a new skyscraper in their place. This reminds us of another seminal aspect of the nouns "wall" and "foundations", which have a Latin root, "vallum" and "fundatio", thus making us aware that their figurative meaning (an obstacle, and old rules and ideas) again help to corroborate the need to destroy or remove the old in crder to build the new. Extending these considerations to the creative process, or, specifically to the art of poetry, one 
can see the implications of these two words of Latin origin (old rules of writing verse which have to be removed, for they are obstacles for new developments) in contrast to the other nouns related to building, such as "skyscraper", of Anglo-Saxon (Old Norse) origin, but actually a neologism if compared to "foundations" and "walls".

In this way, one can see how the nouns used in the poem are almost technical, familiar to steelworkers in general, while the verbs connote movement, action, kinesis, in contrast to the only verb in the poem outside the above paradigms, which is "be", connoting stasis. The creative process is once more apparent, then, for from the nouns suggesting the tearing down and then the constructing of skyscrapers, to the verbs conveying the creative process in movement, we reach the verb "be", implying that the process has come to an end. But even this ending is not a complete stasis, for the nail is "holding a skyscraper", conveying continuity in the act of holding, in the same way that the final adverbial clause "through blue nights into white stars" makes us leave the realm of the city and of buildings to reach nature again, in the form of dark blue nights and brilliant white stars.

Let us still show how on the syntagmatic level the poem also offers some relevant parallelisms in relation to the central idea - the transformation of steel - and how this is gradually deveioped through repetition and variations up to the last line of the poem. Thus, in the same way that words couid be classified into paradigms, the lines can also be classified into syntagms, as seen in the diagram below:

We can see how these syntagmatic units loosely classified as Verbal Phrases, Noun Phrases and Adverbial Phrases form recurring patterns, with parallelistic effects, for lines 1 and 5 are repeated, thus confirming the idea of a prayer peing uttered; lines 2 and 6 are parallelistic, by the fact that the words are repeated up to "crowbar" in line 2 and "steel spike" in line 6. This parallelistic effect is one of similarity on the one hand, for steel is uttering a wish of being transformed into an instrument of destruction - the crowbar while on the other hand, steel wishes to become an instrument of reconstruction - the steel spike - in this way 


\begin{tabular}{|c|c|c|c|c|c|c|}
\hline $\begin{array}{l}\text { Lay } \\
\text { Beat } \\
\text { Let } \\
\text { Let } \\
\text { Lay } \\
\text { Beat } \\
\text { Drive } \\
\text { Take }\end{array}$ & $\begin{array}{l}\text { me } \\
\text { me } \\
\text { me } \\
\text { me } \\
\text { me } \\
\text { me } \\
(\ldots)\end{array}$ & $\begin{array}{l}\text { and hammer } \\
\text { and hammer } \\
\text { and fasten }\end{array}$ & $\mathrm{me}$ & $\begin{array}{l}\text { pry loose old walls. } \\
\text { lift and loosen old foundations. }\end{array}$ & $\begin{array}{l}\text { on an anvil, } \\
\text { into a crowbar. } \\
\text { on an anvil, } \\
\text { into a steel spike } \\
\text { into the girders } \\
\text { into the central gi }\end{array}$ & $\begin{array}{l}\text { O God. } \\
\text { O God. } \\
\text { irders } \\
\text { re) }\end{array}$ \\
\hline \multicolumn{4}{|c|}{ Verbal Phrase } & Noun Phrase & \multicolumn{2}{|c|}{ Adverbial Phrase } \\
\hline
\end{tabular}


bringing to the foreground again the paradoxical element in the act of creation: to build, to break, to rebuild. In this way, "crowbar" and "steel spike" contrast as to their semantic function, but not as to the material they are made of.

Still in relation to the parallelistic effects of these different lines of the poem, this grammatical repetition of the same statement, of the same fundamental sentence, in each prayer, with variations, we could say that this reminds us of an amplifier. Amplification is patent, as can be seen, not cniy in the repetition of one of the words of a line, or of a similar idea or image, in the next line, but it is also shown in the fact that the last line of the poem contains and expands to the infinite the basic theme of the poem: the wish to trascend the limitations of steel and become an instrument of destruction, first, in order to make place for the building of a new skyscraper. One can thus see now the asymmetric lineation of the poem, mentioned above, confirms this boldness of aspiration in the prayers of steel, for, from the gradual amplification of the same basic theme, through the different syntagms, we reach the longest line of the poem which becomes visually emblematic of the steel spike and of the great nail, by its foregrounded length, in the same same way that in it, amplification has reached its climax. This is why we have not included the last line inside the diagram above, for it transcends the action of the verbs of movement to reach a verb of state, as it also trancends the function of the "nail" by making it reach out into the infinite. We cannot see the ond of the skyscraper anymore, nor the end of the nail holding it.

Extrapolating the above paradigm into the realm of poetry, we can show the extent to which this poem parallels the creative process:

God $=$ the Creator, the Poet

Anvil, Hammer (instruments used) $=$ paper, pen

Steel (material used) $=$ words

Crowbar, steel spike, the great nail (created objects) = sentences

Loose old walls, old foundations (destroyed objects) $=$ traditional poetic forms. 
Skyscraper (new created object) = the poem, the new work of art.

In this manner, the poem becomes iconic of the creative process for, in the same way that the anvil - this large, heavy blcck of iron on which shapeless metal is hammered into shape, this foundation on which a formless thing is beaten into form - is the staring point of the transformation of steel into an artifact, so paper is tise starting point for the transformation of words into a work of art. But this newly rreated object is also able to remove or destroy the obsolete object that has preceded it and has become stale and outdated and this break with past traditions is a constant in any field of art for, although the old has to exist in order to prepare the way for the new, it has also to be (at least partially) removed, so that a new tradition can establish itself. Thus this contradictory aspect of construction, demolition ancl reconstruction is seminal for the understanding of the poem as is it apparent not only in many other of Sandburg's poems, but also in art in general. But this new work of art is always amitious enough to aspire to the infinite and the eternal, transcending its materialism and reaching immortaiity, for the anvil has become a platform from which wild wishes and prayers are launched into the infinite. And, although this continuous process, monotonous, painful and seemingly endless, of becoming, seems to have reached an end in "be the great nail", the act of "holding", as mentioned, again conveys an action without an end, and thus the ascent of the nail into the stars is infinite.

We could then end by saying that the paradox implicit in the title has been solved, for the prayers of steel contain the personification of a pre-form into a form and a soul, for steel is not only matter but also, through suffering and transformation, a spirit longing for the infinite. There exists, consequently, an analogical structure icetween the form and the meaning of the poem, between the work of steel and the aspiration of steel. Besides, the dialectical process is thus clearly established, for the paradoxical union of contradictory aspects is visible in the prayers of steel: to create, to ciestroy, to re-create. 
In this way, if the last line is an icon of the great nail of steel, holding a skyscraper through blue nights into white stars, the whole poem is also iconic of the creative process, which Sandburg was trying to demonstrate, through "Prayers of Steel".

\section{RESUMO}

O objetivo desta análise é mostrar como Carl Sand. burg, um dos pioneiros da "Pequena Renascença" na poesia norte-americana, foi capaz de projetar, através de seu poema "Preces de Aço", não apenas muitas das caracteris. ticas da nova poesia mas conseguiu transformar o poema em icone do processo criativo que o artista atravessa, enquanto trabalha sua obra de arte.

\section{BIBLIOGRAPHICAL REFERENCES}

1 LEECH, G.N. \& SHORT, M. Style in fiction, London, Longman. 1981. $402 \mathrm{p}$.

2 SANDBURG, C. Prayers of steel. In: FULLER, E. \& KINNICK, B.J. Adventures in American literature. New York, Harcourt, Brace \& World, 1963. v. 2, p. 199. 